\title{
Ireland's economy: Still riding the globalisation wave
}

Written by: David Haugh

Last update: 18 February 2016

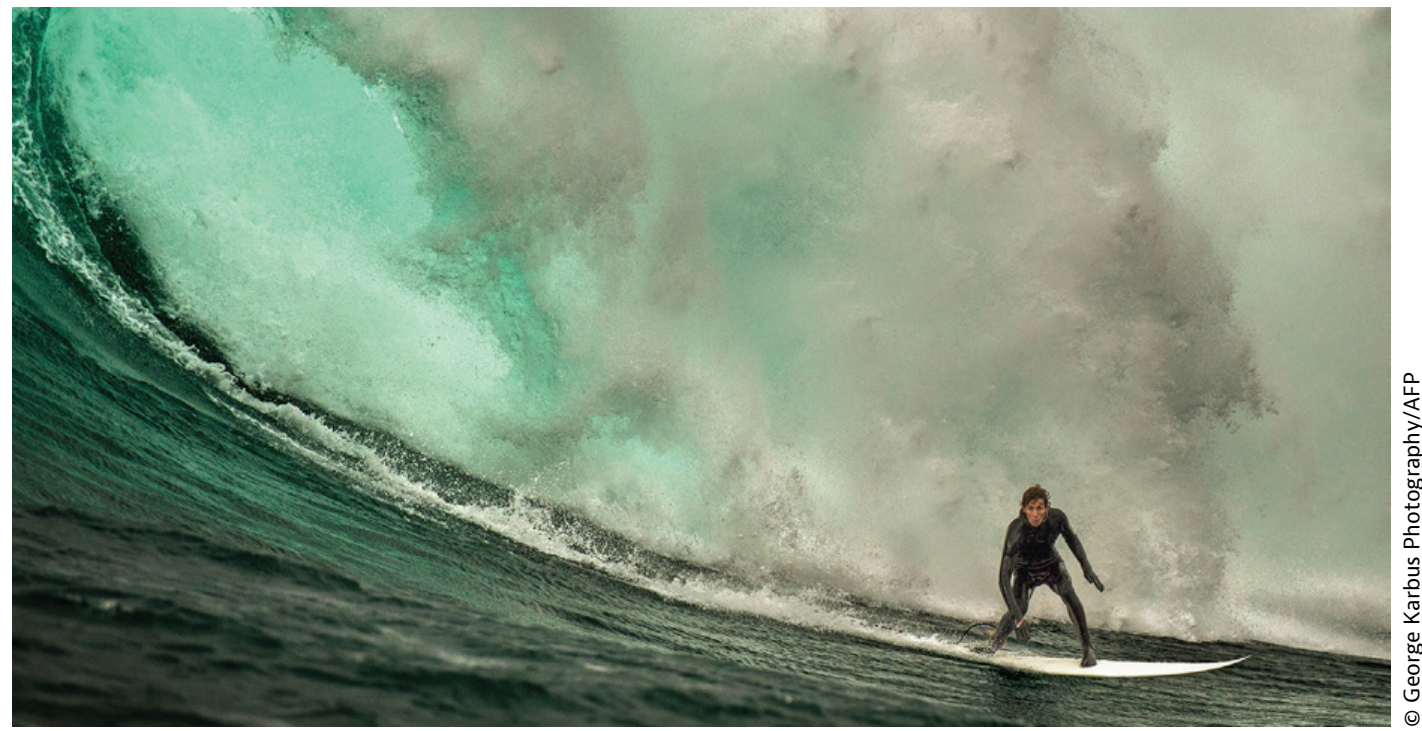

The recession in Ireland was long and deep, but has been followed by a marked recovery. Why is the expansion in Ireland so strong?

At the Cliffs of Moher, on the west coast of Ireland, surfers test their limits in an emerald barrel, Aileens, one of the world's great surfing waves. Like those surfers, Ireland is back up after a banking and fiscal wipeout and riding the globalisation wave again, and in style. Ireland has come a long way since the dark days at the end of 2010, when-with a broken banking system and locked out of sovereign debt markets-it entered a three-year EU-IMF programme. In 2016 the economy should expand by over $4 \%$; while that is slower than the more-than- $6 \%$ real growth notched up in 2015, it would maintain Ireland's place as the fastest-growing OECD economy for the third year running. The public deficit has fallen steadily to $2 \%$ of GDP, public debt has declined from a peak of $120.3 \%$ to around $100 \%$ of GDP, and the banking system is back on its feet. Jobs growth is robust, with the unemployment rate sliding down from a peak of $15.1 \%$ to $9.3 \%$. Recessions caused by banking crises are notoriously long and recoveries muted, as several other EU countries have found out. The recession in Ireland was indeed deep and 
protracted, so why has the expansion in Ireland been so strong? In two words: foreign investment.

Between 2009 and 2013, an extraordinary $€ 125$ billion (61\% of GDP) of foreign direct investment (FDI) flowed into Ireland. Even in the midst of the banking and fiscal crisis and emigration surge, quietly, almost under the radar, foreign capital and brains continued to flow into Ireland. The most visible evidence of this lies in socalled "Silicon Docks", situated in the rejuvenated docklands of Dublin port. This is the heart of Ireland's information technology (IT) cluster. Long-standing investors in Ireland, such as IBM and Microsoft, have now been joined by the European, Middle Eastern and African headquarters of the biggest new names in software, online services and social media, like Google, Facebook, Twitter, Airbnb and LinkedIn.

But Ireland's success riding the globalisation wave goes far beyond the new economy. Three other key sectors-pharmaceuticals, medical devices and financial services-have also enjoyed a tide of investment: eight of the top 10 global pharmaceutical companies have a significant presence in Ireland centred on Cork, while half of the world's top 50 banks and top 20 insurance companies operate out of the International Financial Services Centre in Dublin.

These investments did not happen overnight: Ireland's policy makers have laid the ground to attract capital over decades, at least going back to the 1960s when, thanks partly to OECD advice, a major effort was made to boost education and promote Ireland as a European enterprise destination. By the 1990s, Ireland had developed high-value attributes for innovative global business that the latest financial crisis did not remove.

However, like riding the Aileens barrel, the globalisation wave requires a constant adjustment and flow of new ideas-witness the transformation of Ireland's IT sector from hardware in the early 1980s to software in the 1990s and 2000s, and pharmaceuticals from basic chemicals to active ingredients.

Moreover, for all its progress, Ireland's innovation system still lags behind other small advanced countries, such as Austria, Denmark, Finland, Sweden and Switzerland, where business investment as a percentage of GDP is at least twice as high as in Ireland. Boosting this innovation dimension is the key to Ireland's long-running goal to unlock greater spillovers from the huge pool of foreign investment to Irish-owned firms. Dublin's Silicon Docks, Cork's marine technology and Galway's medical devices sector show what can be done as clusters of foreign and local firms, supported by fine universities and research centres. But more is needed.

Bluntly speaking, it's either move up in the innovation system or move out. There is nothing automatic about linkages between the foreign and local firmsmultinationals source worldwide along complex value chains. If locally owned firms succeed in these clusters, it is because they have developed smart products 
and services to sell and give their multinational clients an advantage over competitors. These spin-offs remain too limited, and spreading such successes requires tuning up the innovation system to better serve the needs of small dynamic firms, which are the harbingers of new, value-enhancing business in most cutting-edge economies.

Research organisations that focus on shorter-term product- and process-related research are required-Enterprise Ireland's new Technology Centres have promising potential in this regard. Ireland has expanded its tax credit for research and development (R\&D), and it has many features of international best practice. This is a clever step, since R\&D tax credits don't lead to the old trap of picking winners. However, tax credits assume a certain cash flow, which small start-ups might not have. Instead, direct R\&D funding would suit smaller firms more, and some rebalancing of policy in this way would help them innovate. Building small firm capacity to absorb new ideas is also important; expanding industrial doctorate and master's programmes that link enterprise to research institutions would generate a new cohort of entrepreneurs. Finally, generating spillovers from FDI requires patience, a lot of it-local firms only started to join the medical devices cluster a decade after the first core foreign investors arrived in Ireland.

Even if Ireland gets all this right, it still faces the challenge of getting more people on board for the ride. Despite Ireland's return to strong growth, a large group of people remains stranded on the beach, unable to reap the benefits. Long-term unemployment is all too high and the employment ratio is low at around $62 \%$, compared with over $70 \%$ in Scandinavia and the UK. In Ireland there are high rewards for being educated- teachers' salaries are among the highest in the OECD area, for instance-but stiff penalties for the less skilled. This gap, partly a consequence of Ireland's globalised economy, contributes to the highest rate of inequality at market income in the OECD. 


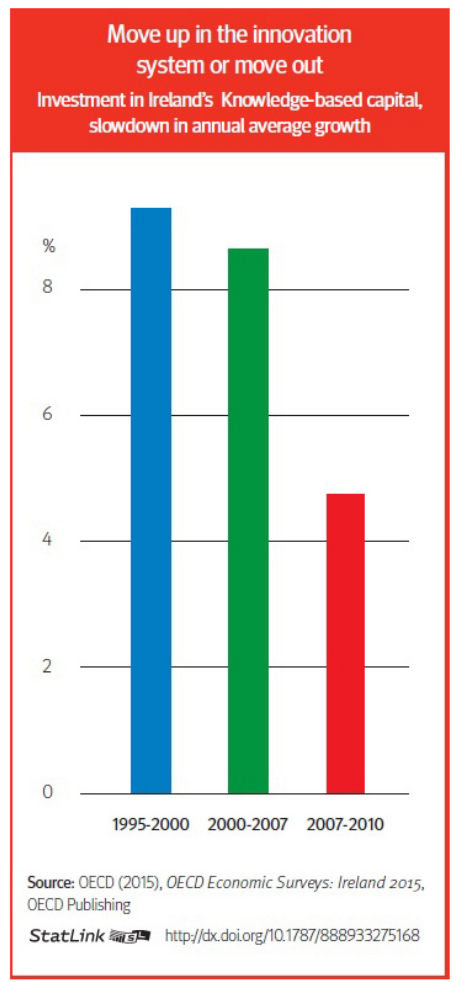

http://dx.doi.org/10.1787/888933275168

OECD (2015), OECD Economic Surveys: Ireland 2015, OECD Publishing

The fact that there is not more discontent and a more destabilising social divide owes something to Ireland's generous tax and welfare system, which brings inequality down to around the OECD average. However, the social consensus that has long underpinned policy making is not beyond risk. For a start, welfare is expensive, requiring high taxation rates, even on relatively modest incomes. Strikingly, workers start paying almost the highest marginal income tax rate on around the average wage, compared to just over five times the average wage for the OECD as a whole.

Clearly, their tax would be better served developing the potential talent and perspectives of everyone, including those out of work, rather than funding welfare to such an extent that it keeps far too many people inactive in what risks becoming a two-speed Ireland. The solution is to get a wider cross-section of people back into activity. The government has started to advance this approach by adopting more active labour market policies. Improving training for the unemployed and reducing high marginal effective tax rates at low incomes (some families face a marginal effective tax rate of $60-70 \%$ on incomes between $€ 16000$ and $€ 32000$ per annum!) that penalise going out to work should now be priorities. 
It is said that a crisis is an opportunity, and Ireland can emerge stronger and more innovative than before. If Ireland can create a world-class innovation system to bridge its foreign and domestic firms, while opening up the jobs ladder for everyone, it'll handle the twists and rolls of the next the globalisation wave with aplomb.

\section{References}

Kennedy, Seán et al. (2015), “Taxes, income and economic mobility in Ireland: New evidence from tax records data", OECD Economics Department Working Papers, No. 1269, OECD Publishing http://dx.doi.org/10.1787/5jrqc6zlgq31-en

O'Connor, Brendan et al. (2015), "Searching for the inclusive growth tax grail: The distributional impact of growth enhancing tax reform in Ireland", OECD Economics Department Working Papers, No. 1270, OECD Publishing http:// dx.doi.org/10.1787/5jrqc6vk3n30-en

OECD Economic Surveys: Ireland 2015 http://dx.doi.org/10.1787/eco_surveysirl-2015-en

OECD Economic Outlook, Volume 2015 Issue 2 http://dx.doi.org/10.1787/ eco_outlook-v2015-2-en 